\title{
Undetected Delinquent Behavior
}

\author{
Martin Gold*
}

Assistant Program Director, Research Center for Group Dynamics,
Institute for Social Research, University of Michigan; Assistant Professor,
Department of Psychology, University of Michigan

A.B. (Psychology), 1953, Dartmouth College; M.A. (Psychology), 1955 , Ph.D. (Social Psychology), 1961, University of Michigan

The article discusses an interview method designed to measure delinquent behavior directly from the confidential confessions of teen-agers. The method is described and results are presented from a validation study of 125 undetected delinquents. Applica. tion of the measure is illustrated with findings from a study of 522 randomly selected boys and girls, thirteen to sixteen years old, residing in Flint, Mich. Conclusions are drawn about the relationship between delinquency and social status and sex, and about the validity of official records.

$S^{\mathrm{T}}$ TUDENTS OF JUVENILE DELINQUENCY and practitioners who explore the research literature for help in treating delinquents have found that measurements of delinquency have been grievously inadequate. A youngster generally has been labeled "delinquent" either because he has been caught by the police or because his answers to questions about himself are similar to those of youngsters caught by the police.

Social scientists alert to this problem have developed various methods to measure delinquency directly from youngsters themselves, including field observation, self-administered questionnaires, and interviews. Results have been discrepant, as, for example, in studies of the relationship between juvenile delinquency and social status, a relationship

- The author wishes to thank Bert Greene, Donald Halsted, Safia Mohsen, and Margaret Simberg, who worked on various phases of this research; the Juvenile Division of the Flint Police Department and the Pupil Personnel Office of the Flint Public Schools, who gave invaluable assistance; and Dorwin Cartwright, Elizabcth Douvan, Ronald Lippitt, and Alvin Zander, who helped improve the manuscript. upon which many theories of delinquen. cy have been built.

This article introduces an interview method designed to find out from teen. agers how many delinquent acts they have committed in the recent past and to discover other pertinent information about this behavior. $\dagger$

\section{Why Collect Such Data?}

Almost all of the research on delinquency begins in the official records of police, courts, and institutions. A large number of delinquent acts and the identities of children who committed them are unrecorded in these sources. In ad. dition, they may not accurately reflect the distribution of delinquency by sex, social status, race, and other variables.

†This study was part of the Inter-Center Program on Children, Youth, and Family Life. which was directed by Ronald Lippitt and Stephen Withey. The research was supported by Grant M-09-109 from the National Institute of Mental Health.

1 Fred J. Murphy, Mary W. Shirley, and Helen L. Witmer, "The Incidence of Hidden Delinquency," American Journal of Orthopsychiatry, October 1946, pp. 686-96. 
Murphy, Shirley, and Witmer, 1 for example, report that social agency records reveal what everyone suspected-that police never learn who committed most delinquent acts.

Furthermore, as demonstrated in one Michigan city, boys who live in poorer parts of town and are apprehended by police for delinquency are four to five times more likely to appear in some off. cial record than boys from wealthier sections who commit the same kinds of offenses. ${ }^{2}$ These same data show that, at each stage in the legal process from charging a boy with an offense to some sort of disposition in court, boys from different socio-economic backgrounds are treated differently, so that those eventually incarcerated in public institutions, that site of most of the research on delinquency, are selectively poorer boys.

Many well-known social-psychological and sociological theories of delinquency are grounded in data abstracted from official records. ${ }^{3}$ These theories are built fundamentally on the finding that delinquency is related to socio-economic status, although the theoreticians recognize that this relationship may arise from the method by which the data are compiled. We need better data if we are to build and test theories more confidently.

Attempts have been made to collect data on delinquency independently of official records. Case histories in the files of social agencies have been one source of data, but social agencies themselves contact a highly selective popula-

2 Martin Gold, Status Forces in Delinquent Boys (Ann Arbor: University of Michigan, Institute for Social Research, 1963).

3 Albert K. Cohen, Delinquent Boys (New York: Free Press, 1955); Richard Cloward and Lloyd Ohlin, Delinquency and Opportunity (New York: Free Press, 1960).

1 Murphy el al., supra note 1; Sophia M. Robison, Can Delinquency Be Measured? (New York: Columbia University Press, 1996); Clifford R. Shaw and Henry D. McKay, Juvenile Delinguency and Urban Areas (Chicago: University of Chicago Press, 1942). tion, so their files do not adequately sample the population of American adolescents. Other investigators have administered anonymous questionnaires to samples of adolescents ${ }^{5}$ and have produced findings which challenge the reality of the supposed relationship between socio-economic status and delinquency. Clark and Wenninger report:

Our findings are similar to those of Nye. Short and Dentler-Monroe in that we failed to detect any significant differences in illegal behavior rates among the social classes of rural and small urban areas. 6

On the other hand, Reiss and Rhodes? conducted personal interviews with boys in Nashville, Tenn., asking them if they had ever done something at one time or another for which they would have been arrested if they had been caught, and found that "delinquency rates, in general, vary inversely with ... the ascribed social status of the boy."

Because no investigation of undetected delinquency so far has sampled a large representative group of teen-age boys and girls and because results thus far have been so mixed, further work along these lines is indicated.

Beyond the need simply for accurate data on the extent and distribution of delinquencv, descriptions of a large number of representative delinquent acts should give us further insight into the etiology of delinquency. For example, if we were able to distinguish the person who commits delinquent acts in

5 John P. Clark and Eugene P. Wenninger, "Socio-Economic Class and Area as Correlates of Illegal Behavior among Juveniles," American Sociological Review, December 1962, pp. 826-34; Robert Dentler and Lawrence J. Monroe, "Early Adolescent Theft," American Sociological Re. view, October 1961, Pp. 733-43; Ivan E. Nye, Family Relationships and Delinquent Behavior (New York: Wiley, 1958); Austin L. Porterfield and Stanley C. Clifton, Youth in Trouble (Fort Worth, Tex.: Leo Potishman Foundation, 1946) .

6 Clark and Wenninger, supra note 5.

7 Albert J. Reiss, Jr. and Albert L. Rhodes, "The Distribution of Juvenile Delinquency in the Social Class Structure," American Soriologi. ral Review, October 1961, pp. 720-32. 
the company of others from the one whose delinquency is solo behavior, we might be in a better position to sort out various motivations behind delinquency. Or, if we were able to determine precisely what it is that youngsters steal and what they do with the stolen goods, this information would help us distinguish between "utilitarian" and "malicious" forms of delinquency.

\section{Measurement Technique}

\section{The Sample}

We aimed to study a representative set of teen-agers in Flint, Mich., an industrial city of 200,000 people. With the cooperation of the public school system, we selected at random a sample of six hundred from a list of almost all boys and girls thirteen through sixteen years old living in the school district, regardless of whether they were attending public or private schools or had dropped out of school altogether. We eventually interviewed 522 of them, or 87 per cent of those originally selected. A look at the available demographic data on the 6 per cent who refused to be interviewed and the 7 per cent who had moved from Flint indicated that representativeness was not diminished by our inability to interview them. Table 1 describes the distribution of the sample by sex, race, and the occupation of the chief breadwinner in the family.

\section{Introductory Procedure}

We trained local college students in field interviewing techniques. Each interviewer was assigned to interview youngsters of the same sex and race as himself. Interviewers were instructed to turn back an assignment if they or members of their immediate family knew the youngster or the youngster's family.

After sending an initial letter to parents and youngsters announcing a study of what teen-agers do in their spare time, the interviewer arranged by telephone to drive the youngster to a community center, firehouse, or similar facility near his home so that all interviews could be taken under standardized conditions. We suspect that almost all of the thirty-eight refusals were attributable to parental objection to their son's or daughter's leaving the house with the interviewers, a practice we required so the youngster could be interviewed out of earshot of his family.

Table 1

Random Sample

By Sex, Race, and Occupation of Chief Breadwinner in Youth's Family

\begin{tabular}{|c|c|c|c|c|c|c|c|c|}
\hline \multirow[b]{3}{*}{ Occupation (U.S. Census Categories) } & \multicolumn{4}{|c|}{ Male } & \multicolumn{4}{|c|}{ Female } \\
\hline & \multicolumn{2}{|c|}{ White } & \multicolumn{2}{|c|}{ Other } & \multicolumn{2}{|c|}{ White } & \multicolumn{2}{|c|}{ Other } \\
\hline & $\%$ & No. & $\%$ & No. & $\%$ & No. & $\%$ & No. \\
\hline Professional, technical, and kindred & $\overline{4}$ & 23 & - & - & $\overline{4}$ & 21 & - & - \\
\hline Self-employed businessmen and artisans & 3 & 15 & $\bullet$ & 2 & 3 & 18 & - & - \\
\hline Managers and officials & 3 & 18 & - & - & 3 & 17 & $\bullet$ & 1 \\
\hline Clerical and sales & 3 & 17 & $\bullet$ & 1 & 4 & 22 & - & - \\
\hline Craftsmen, foremen, and skilled workers & 12 & 64 & $\mathbf{l}$ & 4 & 12 & 61 & 1 & 4 \\
\hline Operatives and kindred & 9 & 46 & 7 & 35 & 10 & 53 & 5 & 25 \\
\hline Protective services: police, firemen, etc. & 1 & 3 & - & - & 1 & 4 & - & - \\
\hline Laborers, service workers, and unskilled & 1 & 6 & 2 & 11 & 2 & 11 & 1 & 6 \\
\hline \multirow[t]{2}{*}{ Not ascertained } & 1 & 7 & 1 & 6 & 3 & 14 & 1 & 7 \\
\hline & - & L & - & - & - & 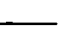 & - & - \\
\hline Total & 38 & 199 & 11 & 59 & 42 & 221 & 8 & 43 \\
\hline
\end{tabular}

- Lew than $.5 \%$. 
During the drive to the interviewing station, the interviewer revealed that the study was about delinquent behavior which may or may not have been detected. He assured the youngster of confidentiality and anonymity, and he stressed the importance of truthfulness. Then he explained the randomness of sample selection and offered the young. ster an opportunity to withdraw from the study.

One boy asked to be returned home at this point. Of course, this does not necessarily mean that the rest were completely honest. Indeed, we know now that some were not.

We elected to employ the method of personal interview for two reasons. First, we wanted to obtain detailed descriptions of delinquent acts, to find out the who, what, when, where, and how of them. Such data are too complicated to get in a self-administered questionnaire.

Second, we suspected that, given a checklist, some youngsters might admit delinquent acts which would turn out not to be offenses at all, while others might overlook actual offenses. Probing by an interviewer on the spot could winnow out the misunderstandings and identify and draw out omissions. Indeed, our subsequent analysis of data shows, for example, that half of the acts of property destruction, one-fourth of the confidence games, and one-fifth of the personal assaults to which our sam. ple initially admitted could not conceivably be called chargeable offenses. We found that such overreporting was sometimes related to other variables in which we were interested; for example, the proportion of confessions of accidental or trivial acts of property destruction was significantly higher among wealthier than among poorer white boys.

We also found that confession of one act sometimes led an interviewer to discover other related delinquencies; for example, about one-third of the thefts involved at least one other chargeable offense, as did 10 per cent of the assaults.
The personal interview has an apparent disadvantage, however. It is reasonable to suppose that offenses would be concealed from an interviewer more frequently than from an anonymous, selfadministered checklist. Later in this article we report a validity study of the personal interview method we used. It throws some light on concealment.

The interview began with the interviewer setting up a large sortboard in front of the respondent. Across the top was written "How often have you ... ?" Under this heading were slots marked "Never," "More than three years ago," "In the last three years ... once, ... . twice, ... three or more times." The slots were large enough to accept a $3 \times 5$ card.

The interviewer placed a packet of fifty-one $3 \times 5$ cards in front of the respondent: "First of all, I'm going to ask you to sort this pack of cards for me. On each card is a statement describing something a fellow or girl might have done, like the first one. ..."

Almost all respondents were able to sort their cards without further instructions. The fifty-one questions inquired about such activities as truancy or disbarment from school, trespass, damage, hitting father, lying, stealing, drinking beer, fighting, arson, smoking, taking a car, fornication, and carrying weapons. Questions on approved activities were also asked. These included mention on the school honor roll, helping charity drives, and working on the school newspaper.

The interviewer questioned the young. ster about those offenses he admitted committing in the last three years. If the youngster indicated he had committed any particular offense more than once in that time, he was asked about each of the two most recent offenses of that kind. A standard form, administered to every respondent, elicited demographic and other data. 
The questions asked about admitted offenses were essentially the same for all offenses, with only minor variations tailored for the specific kind of offense. Figure 1 reproduces the form appropriate to "taking some part of a car or gasoline."

It should be pointed out that, in Questions 5 and 5a ("Were you with anyone? Who were they?"), the respondent was not asked for the names of his delinquent companions, but only their age and sex and their relationship (close friends, acquaintances, etc.).
The interview lasted from thirty-five minutes to over two hours, depending on the extent of the youngster's confessions. Average duration was about an hour and a half.

\section{VALIDATION}

A central problem in this sort of research is the extent of concealment by respondents.

Our interviewers were carefully selected and trained to gain the confidence of their respondents; our entire procedure was built around convincing young-

Figure 1

One Section of the Interview Schedule

Take some part of a car, or gasoline

(If 3 or more times recently) :

1. About how often do (did) you do this?

Once a week or more ....... Two or three times a month

Once a month

Once or twice every four months

Once or twice a year .......

Other (specify)

2. Thinking of the last time you did this, what did you take?

3. Have we covered this in a previous question?

4. Where was this?

4a. About how many blocks was that from your house?

0.2 ...... 3.5 ...... $6.10 \ldots 11.20 \ldots . . .21$ or more ....... 1 mile or more ........

4b. Would you say this was in your neighborhood? Yes No

5. Were you with anyone? Yes ....... No ....... (go to question 6)

(if yes) $5 \mathrm{a}$. Who were they?

5b. Did you actually take part ........ or just watch .......?

6. Whose idea was it to do this? Mine ....... Everyone's agreement

Other (specify)

7. How long had you been thinking about taking this before you took it?

8. Why did you take this (part of car, or gasoline)?

9. What did you do with it? (More than one may be checked.)

Used it

Destroyed or discarded it

Another involved party used it

Gave it to party not involved Sold or traded it

Other (specify)

10. When did this happen?
(a) Year
(b) Month
(c) Day M.... Tu...
W.... Th.....
(d) Time 5 a.m.-Noon Noon.9 p.m. 8 p.m.6 p.m. 6 p.m.-11 p.m. 11 p.m.-5 a.m. (go to Question 12)

11. Did you tell anyone about it later? Yes ............. (go to
(if yes) lla. How many adults and boys and girls did you tell?
Adults
Girls

11b. (if told adults) What relationship are these adults to you?

12. Did anyone catch you? Yes ....... No ....... (go to Question 13)

(if yes) 12a. Who caught you? ...... 12b. How did they catch you?

12c. What happened after you were caught?

13. Did your parents find out about it? Yes ...... No ........

(if yes) 13a. How did they find out?

13b. What did they do or say? 
sters of the scientific nature of the study; and we emphasized in many ways that confidentiality was assured. Nevertheless we expected that some proportion of youngsters would conceal offenses from us. Certain of them felt apprehensive about telling the complete truth. After all, said one boy, the interviewer would "have enough on me to send me up for thirty years." We did not know what proportion of our sample would conceal offenses; we did not know whether concealment would vary with factors like social status, race, and sex; and we did not know whether certain offenses would be concealed more often than others.

To study concealment we found it necessary to interview a criterion group, youngsters about whose delinquency we already had reliable information but who were not aware we had it. We managed eventually to interview 125 youngsters under these conditions.

\section{Procedure}

Our strategy was first to contact teenagers who seemed likely to have information about the delinquency of other boys and girls. We were introduced to these potential informants by teachers, youth workers, other interested adults, and by some informants themselves.

We explained the study to potential informants and asked them to help us by supplying names of boys and girls who they knew had committed delinquent acts for which they had not been caught, together with as much as they could tell us about these acts. We also asked them to tell us how they happened to know about the delinquencies they revealed to us, as we accepted no second-hand testimony. The only facts counted as reliable were those which the informants had witnessed themselves or which the delinquent himself had told them.

Over fifty potential informants were obtained, and more than forty of them agreed to cooperate. They were not all equally helpful. Some could not or would not give us any reliable information; others supplied us with as many as seven names along with complete descriptions of the delinquencies, often based on participant observation.

Table 2 describes the validation sample by categories of race, sex, and social status. The status distinction is primarily between blue-collar and white-collar workers. Because higher status Negroes are rare in Flint, few fell into our random sample of 522 teen-agers, so we did not at this time make any attempt to obtain a validating set of higher status $\mathrm{Ne}$ gro teen-agers.

An interviewer was assigned to a youngster in the validation sample without any prior knowledge of what offenses his respondent had committed; indeed, in most cases he was unaware that his respondent was not among the random sample. The interviewing procedure was the same as the one used with the random sample.

Our data on concealment came from comparisons of the responses of the 125 validating respondents with what our informants had already told us they had done. We considered a youngster a truthteller if he told us what our rele-

Table 2

Validation Sample

\begin{tabular}{|c|c|c|c|c|c|}
\hline \multirow{2}{*}{$\begin{array}{l}\text { Social } \\
\text { Status }\end{array}$} & \multicolumn{2}{|c|}{ Male } & \multicolumn{2}{|c|}{ Female } & Total \\
\hline & White & Other & White & Other & \\
\hline$\overline{\text { Higher }}$ & 19 & - & 14 & $\overline{-}$ & \\
\hline \multirow[t]{3}{*}{ Lower } & 31 & 21 & 20 & 20 & \\
\hline & - & - & - & - & \\
\hline & 50 & 21 & 34 & 20 & 125 \\
\hline
\end{tabular}


vant informant had told us, or if he told us about more recent offenses of the same type, or if he told us about more serious offenses. A respondent was considered a concealer if he did not confess to an offense about which an informant had told us, or to any more recent similar offense, or to any more serious of fense. Youngsters were categorized as questionables when they told us about offenses which were similar to but did not exactly match offenses about which we already had information. In such cases we were not certain whether something was being deliberately concealed or distorted or whether he memories of informants and respondents merely differed.

\section{Results}

Table 3 presents the findings of the validity check by the sex, race, and social status of respondents. Overall, 72 per cent of the youngsters seemed to tell us everything which informants had told us; 17 per cent appear to be outright concealers; the rest are questionables.

While the proportion of truthtellers differs somewhat from one category to another, no difference falls below the .20 chance probability level by the chisquare or Fisher Exact Test. We also wondered whether the more delinquent youngsters were more frequently the concealers. But a comparative check revealed no reliable differences.
Specific offenses most often concealed by the male validity sample were breaking and entering, property destruction, and carrying concealed weapons. Although many of each of these offenses were confessed, almost as many of those we had been told about were concealed as were confessed. For example, boys confessed to eighteen acts of breaking and entering about which we had no prior knowledge; but of the ten offenses of this $l:$ d about which we were quite certain, tuur were concealed.

Girls most frequently concealed breaking and entering, property destruction, unauthorized driving away, gangfighting, miscellaneous theft, and fornication.

\section{Limitations}

The validation study is far from fool. proof. It is vulnerable in at least two respects:

First of all, the validation study, which is especially concerned with the problem of concealment, does not resolve the problem of exaggeration. We do not know to what extent teen-agers, and boys especially, want to project an image of at least moderate delinquency as a demonstration of daring and manliness. To check would require a criterion group for which we were certain not only of some of the offenses they had committed but also of some which they had not. We learned early in our study that teen-agers could not vouchsafe that

Table 3

Proportions of Truthtellers, Questionables, and Concealers, by Sex, Race, and Social Status

\begin{tabular}{|c|c|c|c|c|c|c|}
\hline Sex & Race & $\begin{array}{l}\text { Social } \\
\text { Status }\end{array}$ & $\mathbf{N}$ & $\frac{\text { Truthtellers }}{\%}$ & $\frac{\text { Questionables }}{\%}$ & $\frac{\text { Concealers }}{\%}$ \\
\hline \multirow[t]{3}{*}{ Boys } & White & Higher & 19 & 74 & 5 & 21 \\
\hline & & Lower & 31 & 71 & 23 & 6 \\
\hline & Negro & Lower & 21 & 86 & - & 14 \\
\hline \multirow[t]{4}{*}{ Girls } & White & Higher & 14 & 64 & 14 & 21 \\
\hline & & Lower & .20 & 75 & 10 & 15 \\
\hline & Negro & Lower & 20 & 60 & 10 & 30 \\
\hline & & & - & - & - & - \\
\hline Total & & & 125 & 72 & 11 & 17 \\
\hline
\end{tabular}


even their closest friends had not committed any particular kind of offense.

One safeguard against exaggeration was the set of detailed questions we asked about each offense. It would have required an especially creative and quick-thinking youngster to fabricate offenses during his interview. In a few cases, interviewers did catch respondents in what may have been exaggeration: some concealed weapons turned out to be Boy Scout pocket knives; some gangfights were nothing more than minor playground scuffles; and some instances of auto theft were only quick spins around the block in the family car.

Although some exaggerations must still be distorting our data, we believe the distortion is quite minor.

Our use of informants-youngsters who are aware of the delinquencies of others-leads to a second possible source of vulnerability in the validation design, which is that we have no information about loners. Youngsters who commit their delinquent acts alone and tell no other youngster about them could not fall into our criterion group. We do not know how much loners are likely to conceal or how much they would gladly unburden, for the sake of science, to an accepting, interested young interviewer.

\section{Indices of Delinguent Behavior}

Measures of delinquent behavior are based on the confessions of the random sample of boys and girls, aged thirteen to sixteen, who lived in the Flint school district in 1960. Of the several indices of delinquency which have so far been constructed from these data, two-Index $\mathrm{F}$ and Index S-are currently employed in our analyses.

\section{Index $F$}

Index $F$ draws data only from the detailed descriptions of delinquent acts which youngsters most seldom concealtrespassing, assault, stealing a part of a car or gasoline, hitting father, hitting mother, drinking alcoholic beverages without parental knowledge or permission, running away from home, gang fighting, shoplifting, larceny, and fornication. This list covers a wide range of offenses, including offenses against persons (e.g., assault) and against property (e.g., theft) ; offenses generally believed to be more typical of boys (stealing a car part or gasoline) and more typical of girls (shoplifting); and offenses generally thought trivial (trespassing) as well as serious (hitting mother).

Since interviewers questioned respondents closely on no more than the two most recent offenses of each type, Index $F$ is not as sensitive as other indices might be to the frequency of delinquent activity, but its correlations with indices which include a wider range of offenses and more information on frequency are .87 and higher.

The major advantage of Index $F$ is that detailed information on the relevant offenses permitted exclusion of all those "offenses" which coders judged not to be chargeable by the police; that is, Index $F$ includes only those offenses which in themselves would clearly have warranted police action if they had been detected. We noted in the first part of this paper that not all of the "offenses" to which youngsters confessed could reasonably be considered "delinquent acts"; 28 per cent were not.

\section{Index $S$}

This index is based on a delinquency index devised by Sellin and Wolfgang, ${ }^{8}$ which takes into account the seriousness of an offense as rated by university students, police officers, juvenile aid workers, and juvenile court judges. Each offense is weighted by some factor which reflects the seriousness with which that offense was regarded by the raters.

Our data were not collected in a way which allows precise application of the

8 Thorsten Sellin and Marvin E. Wolfgang, The Measurement of Delinquency (New York: Wiley, 1964). 
weights prescribed by Sellin and Wolfgang, for our data collection had begun before they had published their index. However, we found it possible to use an approximation of their index, assigning the weights to a set of nine offenses, as described in Figure 2.

Only those offenses were included for which interviewers had obtained detailed information because descriptions of the offenses, their chargeability, and the nature of items stolen or damaged were required in order to assign weights for seriousness.

Because the validation data show that youngsters fairly frequently conceal instances of property destruction and unauthorized driving away of an automobile, Index $S$ in this respect may distort

Figure 2

Offenses and Weights Assigned for Seriousness on Index $S^{*}$

\begin{tabular}{|c|c|}
\hline Offense & Weight \\
\hline Trespass & 1 \\
\hline \multicolumn{2}{|l|}{ Threaten to assault } \\
\hline Without a weapon & 2 \\
\hline With a weapon & 4 \\
\hline \multicolumn{2}{|l|}{ Property destruction } \\
\hline \multicolumn{2}{|l|}{ Cost of estimated damage less than } \\
\hline $\begin{array}{l}\$ 50 \text { or estimated cost not ascer- } \\
\text { tained }\end{array}$ & 1 \\
\hline $\begin{array}{l}\text { Cost of estimated damage } \$ 50 \text { or } \\
\text { more }\end{array}$ & 2 \\
\hline $\begin{array}{l}\text { Assault, the effect requiring medical } \\
\text { attention }\end{array}$ & 4 \\
\hline \\
\hline $\begin{array}{l}\text { Gasoline or inexpensive part (e.g., } \\
\text { hub cap, antenna) or part not } \\
\text { ascertained }\end{array}$ & 1 \\
\hline $\begin{array}{l}\text { More expensive part (e.g., jack, } \\
\text { radio) }\end{array}$ & 2 \\
\hline \multicolumn{2}{|l|}{ Theft, other } \\
\hline $\begin{array}{l}\text { Worth less than } \$ 50 \text { or worth not } \\
\text { ascertained }\end{array}$ & l \\
\hline Worth $\$ 50$ or more & 2 \\
\hline Arson & 2 \\
\hline Shoplifting & 1 \\
\hline $\begin{array}{l}\text { Driving away an auto without the } \\
\text { owner's permission }\end{array}$ & 2 \\
\hline
\end{tabular}

- Modification of delinquency index by Sellin and Wolfgang. the absolute level of delinquency and the relative delinquency of youngsters in the sample.

\section{Comparisons}

Figure 3 presents the distributions of the two delinquency indices, each one a different way of organizing the youngsters' responses. A reader familiar with social scientific data will recognize the familiar J-shape of the curves generated by the distributions of the delinquency indices. Allport ${ }^{\theta}$ has observed that this is just the shape of curve one should expect from data on deviations from recognized norms. That is, most people stick closely to the rules, and the curve drops off sharply and bottoms out at its more deviant end. In this case, most youngsters are not very delinquent, either in the frequency or seriousness of their delinquent behaviour, and there are relatively few youngsters at the more delinquent ends of the curves.

The rank order (rho) correlation between these two indices is .68 , a statistically reliable correlation $(\mathrm{p}<.001)$. These indices are highly correlated with one another as one might expect since they are both based largely on the same set of responses. However, correlations among several indices reveal that Index $S$, which takes into account a judgment of seriousness of the offense, stands somewhat apart from the others. Material presented later will demonstrate that the data on official records and the data collected from Negro boys turn out somewhat differently when seriousness is taken into account from when it is not. This difference makes Index $S$ of special interest.

\section{Illustrative Cases}

The meaning of a score on a delin. quency index will be more clear from the following examples of youngsters with different scores:

9 Floyd H. Allport, "The J-curve Hypothesis of Conforming Behavior," Journal of Social Psychology, May 1934, pp. 141-83. 
Figure 3

Frequency by Distribution of Scores on Delinquency Indices
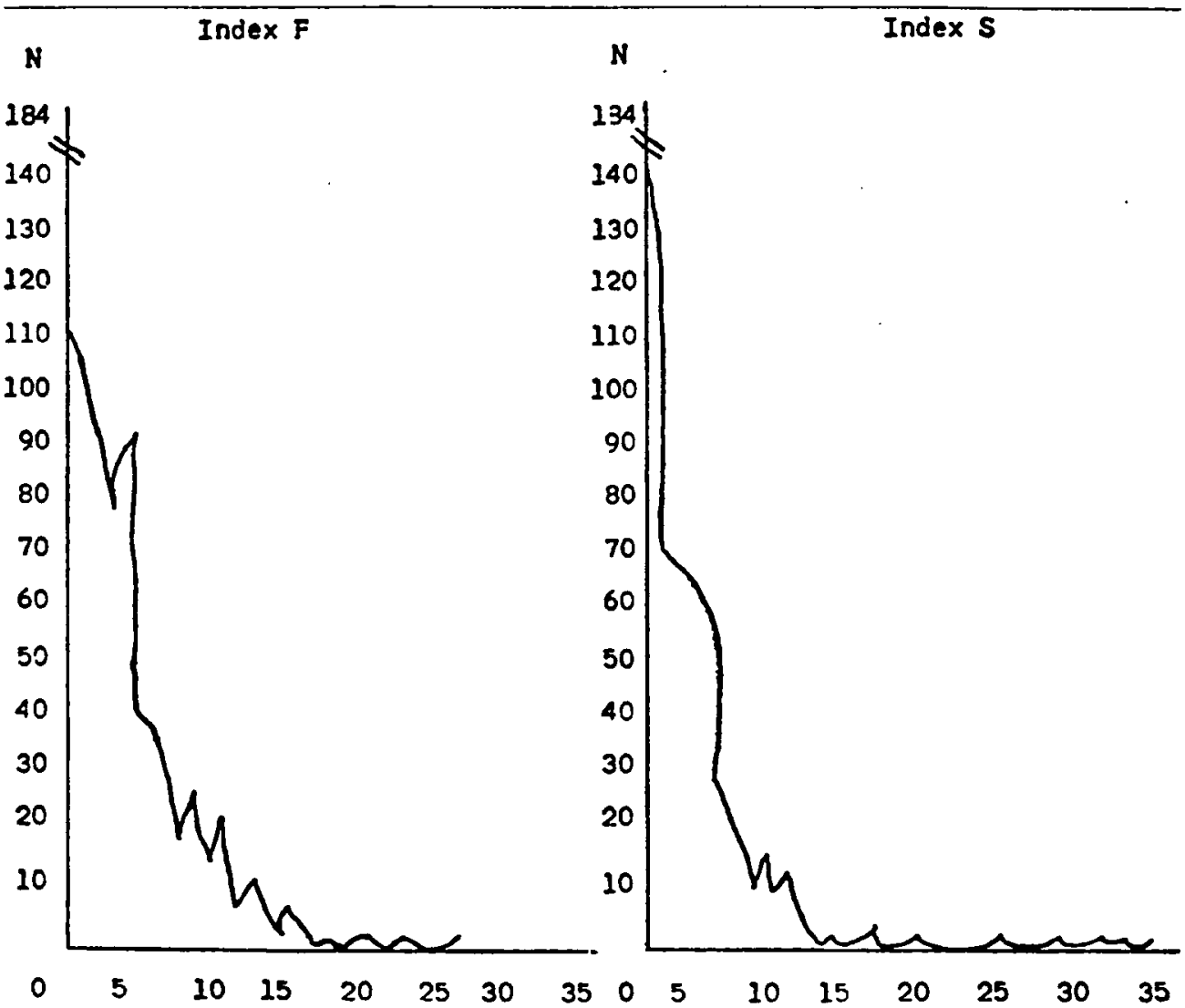

Case 115 (Index $F=00 ;$ Index $S=00$ ). -The respondent was a thirteen-yearold boy in the ninth grade. His mother and father are teachers. The boy is an active Boy Scout and an honor roll stu. dent. He was interviewed in October 1961.

He had played truant once, more than three years ago, and currently lies about his age when he goes to the movies so that he can get in for the children's price. "But the price is so high, I seldom go to the movies anymore," he said. "When I do, I save money on the ticket so I can buy popcorn and candy."

Case 297 (Index $F=04$; Index $S=06$ ). -The subject here is a fifteen-year-old girl in the eighth grade. Her stepfather is a foreman for a beer distributor. She was interviewed in December 1961.
On December 6, 1958, her birthday, she ran away from home because her parents were fighting so much, and she said, "I got real nervous and scared." After wandering about Flint for hours, she went to her maternal grandmother's house, where her mother came to fetch her home.

Sometime in the summer of 1960 she and a friend went exploring in a house under construction. They found a case of beer, probably cached there by the workmen, and took it and some nails. They brought the loot to her stepfather, who spanked her soundly and made her take it all back.

In January 1961 she stole a phonograph record from a department store. Explaining her reason for this she said, "I wanted it and didn't have enough money with me."

In October 1961 she took some doll's clothes and three little bells from a department store. "I gave them to my little sister for a surprise," she reported. 
Case 026 (Index $F=14 ;$ Index $S=15$ ). -This fifteen-year-old boy is in the eighth grade. His stepfather runs a baling machine in a container manufacturing plant; his mother works part-time as a salesclerk in a large department store downtown. He is on a basketball team in his junior high school and has been a class officer. He was interviewed in August 1962.

In May 1961 he and a friend entered a barn on a farm outside of Flint, played around in the hayloft awhile, then left.

In July he and some friends stole two hubcaps from cars parked outside a Flint dance hall and sold them.

In August he stole the net from a basketball hoop on a school playground and gave it to a friend for the hoop over his garage door.

On a Friday night that August he and some friends got into a fight with "some northside niggers."

Again in August he and some friends stole an air mattress, a portable icebox, a six-pack of beer, and the spark from the outboard motor of a boat left unattended at a pier. The boys drank the beer and divided the rest.

In September, he pulled his switchblade knife on "a big Italian boy" who had taken his notebook.

Later in September he and his friends pried open trunks of cars at the Armory parking lot and stole two tires, which were given to one of the group who had been driving them around in his car for several months.

In December he and some friends stole two cases of soda pop from a laundromat, drank what they wanted, and discarded the rest.

In January 1962 he shoplifted fishhooks, gloves, and two friendship rings from stores in a shopping center. "We had a kind of club like," he said, "and we decided to get this stuff."

During January he participated in two successive Saturday night drinking parties. At the first, he drank liquor at a friend's house when the friend's parents were not at home; at the second, he drank beer, bought by an older boy, in a car parked behind a school.

\section{Social Status and Juvenile. DELINQUENCY}

We noted earlier that social scientists have long maintained that more lowerclass youngsters are delinquent than are their middle-class peers. This relationship and the theories built from it have guided the major efforts to combat delinquency in action programs such as the current Federal War on Poverty, New York City's Mobilization for Youth, and the Chicago Boys Clubs Youth Development Project, all designed to alleviate in some way the condition of lower status life. There has, however, always been a persistent set of competent researchers who question the belief that lower status youngsters are the most serious and frequent offenders because of their lower status. They maintain that this relationship is only an artifact of the way data on delinquency are gathered. Probably a substantial portion of the American public shares these researchers' suspicions that the rich kids get away with delinquency and the poor kids get records.

Our measurement of undetected delinquency is free from the selectivity which exists in the records of police, courts, and social agencies. It allows us to examine the relationship between social status and delinquency; to see to what extent this selectivity does exist in the official records; and to determine to what extent official records truly reflect the actual distribution of delinquency among different social strata.

Our findings indicate that social status is indeed inversely related to juvenile delinquency, that more lower status youngsters commit delinquent acts more frequently than do higher status youngsters. However, the data allow us to be more specific about who among lower status youngsters are more likely to be delinquent and enable us to place important qualifications on the general statement of the relationship. 


\section{The Meaning of "Social Status"}

"Social status," as we use the term here, refers to the prestige hierarchy of occupations in our society. There is a great deal of agreement in the United States about the relative prestige of occupations $^{10}$ and a great deal of stability to the prestige hierarchy. ${ }^{11}$ In this paper, a youngster's "status," unless otherwise qualified, refers to social status based on father's occupation.

The specific measure of status used here is $O$. D. Duncan's scale of occupations, ${ }^{12}$ which is based on national studies of the prestige of occupations in the United States. These studies demonstrated that income and education are the two most important determinants of the prestige of an occupation. By computing the average income and level of education achieved by persons in each occupational category and making some adjustments for their ages, Duncan assigned a status score to a large number of occupations.

\section{Selectivity in the Official Records}

These data demonstrate that official records exaggerate the delinquent behavior of boys from lower status homes relative to their higher status peers. (Since only five of the 264 girls in the sample reported being caught by the police, the analyses of these data refer mainly to the boys.)

Police are more likely to record offcially those offenses committed by lower status youngsters, the children of semiskilled and unskilled men. Table 4 documents this statement. Only about 3 per cent of all the chargeable offenses

10 Wellman L. Wamer, M. Mecker, and $\mathbf{k}$. Eels, Social Class in America (Chicago: Science Rescarch Associates, 1949).

11 Robert W. Hodge, Paul M. Sicgel. and Peter H. Rossi, "Occupational Prestige in the Lnited States, 1952-63," American Joumal of Sociology. November 1964, pp. 286-302.

12 Albert J. Reiss, Jr., Otis D. Duncan, Paul k. Hatt, and C. C. North, Occupations and so. rial Status (New York: Frec Press. 1961).
Table 4

Police Referral to Court of Offenses Committed by Lower Status Youngsters Compared with Offenses Committed by Middle Status Youngsters

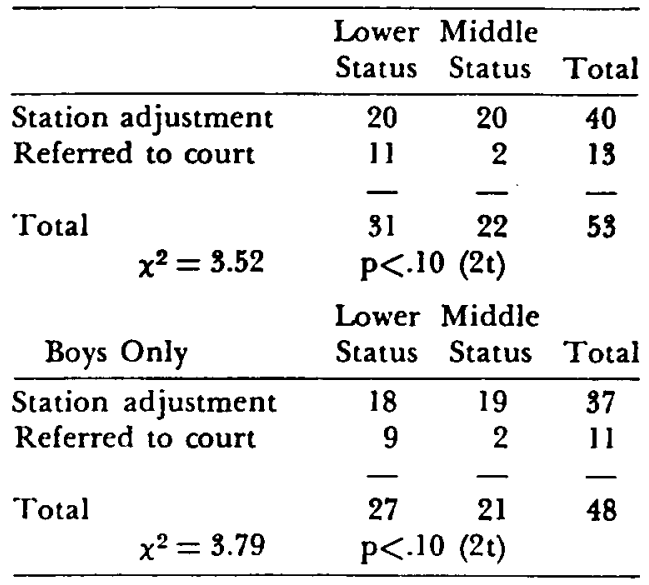

reported by the youngsters in the sample resulted in police apprehension of the offender, and, if the offender came from a higher status family, police were more likely to handle the matter themselves without referring it to the court.

Some judgment by the police about the ability of a family to control its son's behavior is likely to be a major factor in determining whether official action will be taken. Lower status families as a

Table 5

Relationship between Delinquency and Social Status (Boys Only) Demonstrated by Court Records

\begin{tabular}{lcc}
\hline Social Status & $\mathrm{N}$ & $\begin{array}{c}\% \text { Who Have } \\
\text { Records }\end{array}$ \\
\hline $\begin{array}{l}\text { High (professionals, } \\
\text { managers, etc.) }\end{array}$ & 34 & 3 \\
$\begin{array}{c}\text { High middle (skilled } \\
\text { workers, foremen, } \\
\text { white collar, etc.) }\end{array}$ & 104 & 9 \\
$\begin{array}{l}\text { I.ow middle (opcratives. } \\
\text { semiskilled. etc.) } \\
\text { Low (laborers, } \\
\text { unskilled, etc.) }\end{array}$ & 79 & 14 \\
\begin{tabular}{l} 
Total \\
\hline
\end{tabular} & 40 & 15 \\
\hline
\end{tabular}


group are judged less able to keep their sons out of trouble, so official action is more often taken.

Partly as a result of this procedure, court records in Flint demonstrate the usual relationship between delinquency and social status: greater proportions of boys are adjudged delinquent as one goes from higher to lower status categories. The proportion listed in Table 5 , showing that four to five times more lower status boys are delinquent than higher status boys, is a common ratio in the delinquency literature.

Do Official Records Reflect the Amount of Delinquent Behavior?

While official records are selective in a way which exaggerates the relative delinquency of lower status youngsters, they may nevertheless approximate real

\section{Table 6}

Proportion of Boys at Each Level of Delin. quency (Index S) Who Report Being Caught by Police at Least Once

\begin{tabular}{|c|c|c|c|}
\hline & Index S & $\mathbf{N}$ & $\begin{array}{c}\% \text { Report } \\
\text { Caught }\end{array}$ \\
\hline \multirow[t]{3}{*}{ Low } & $0-2$ & 83 & 7 \\
\hline & $3-4$ & 56 & 5 \\
\hline & 5.8 & 60 & 26 \\
\hline High & $9+$ & 58 & 28 \\
\hline \multirow[t]{2}{*}{ Total } & & 257 & 16 \\
\hline & \multicolumn{2}{|c|}{$\begin{array}{c}\mathrm{rpb}=.32 \\
\mathrm{p}<.001\end{array}$} & \\
\hline
\end{tabular}

Table 7

Proportion of Boys at Each Level of Delinquency (Index F) Who Report Being Caught by Police at Least Once

\begin{tabular}{|c|c|c|c|}
\hline & Index $F$ & $\mathbf{N}$ & $\begin{array}{c}\text { \% Report } \\
\text { Caught }\end{array}$ \\
\hline \multirow[t]{3}{*}{$\overline{\text { Low }}$} & $0-1$ & 52 & 2 \\
\hline & 2.4 & 87 & 10 \\
\hline & 5.7 & 62 & 12 \\
\hline High & $8+$ & 56 & 19 \\
\hline \multirow[t]{2}{*}{ Total } & & 257 & 16 \\
\hline & \multicolumn{2}{|c|}{$\begin{array}{c}\mathrm{rpb}=.40 \\
\mathrm{p}<.001\end{array}$} & \\
\hline
\end{tabular}

delinquent behavior. For example, even though most juvenile offenses do not result in the apprehension of the offender and few juvenile offenders are on record with the authorities, the more delinquent youngsters may have been detected and recorded.

Only boys are included here in the analysis of the data since only five girls in the sample have official records, and only six report being caught by the police.

It is clear from the data in Tables 6 and 7 that the more delinquent boys are more likely to be caught by the police. Sixteen per cent of the boys report being caught at least once; but, compared with the least delinquent boys, about four times as many of the most delinquent boys on Index $S$ are caught, and about seventeen times as many when Index $F$ is the measure of delinquency. Since Index $F$ emphasizes frequency of offenses, while Index $S$ emphasizes seriousness, these data suggest that frequency of offenses is a greater determinant of being caught than their seriousness. Erickson and Empey ${ }^{13}$ come to the same conclusion on the basis of their data on Utah boys.

Do the figures on boys "booked" presented in Table 10 reflect degree of delinquency as the contact records do? The data show that about five times more of the most delinquent boys are booked than the least delinquent boys.

Furthermore, it seems that the seriousness of an offense is taken into account in the decision to book a boy. The data have shown that frequency is a greater determinant of apprehension than seriousness; data in Table 8 show that the most serious offenders, high on Index $S$, are about as likely to be booked as the most frequent offenders, high on Index F. Of course, most of the boys high on one index are also high on the other.

\footnotetext{
13 Maynard L. Erickson and LaMar T. Empey, "Court Records, Undetected Delinquency and Decision-Making," Journal of Criminal Lau', Criminology and Police Science, December 1963. Pp. 456-69.
} 
Table 8

Proportion of Boys at Each Level of Delinquency Who Have Been Booked

\begin{tabular}{|c|c|c|c|c|c|c|c|}
\hline \multicolumn{4}{|c|}{ Index $F$} & \multicolumn{4}{|c|}{ Index $S$} \\
\hline & $\begin{array}{c}\text { Level of } \\
\text { Delinquent } \\
\text { Behavior }\end{array}$ & $\mathbf{N}$ & $\begin{array}{c}\% \\
\text { Booked }\end{array}$ & & $\begin{array}{c}\text { Level of } \\
\text { Delinquent } \\
\text { Behavior }\end{array}$ & $\mathbf{N}$ & $\begin{array}{c}\% \\
\text { Booked }\end{array}$ \\
\hline Low & $\begin{array}{l}0-1 \\
2-4 \\
5-7\end{array}$ & $\begin{array}{l}52 \\
87 \\
62\end{array}$ & $\begin{array}{l}4 \\
9 \\
6\end{array}$ & Low & $\begin{array}{l}0-2 \\
3-4 \\
5-8\end{array}$ & $\begin{array}{l}83 \\
56 \\
60\end{array}$ & $\begin{array}{r}4 \\
5 \\
13\end{array}$ \\
\hline High & $8+$ & 56 & 21 & High & $9+$ & 58 & 21 \\
\hline Total & $\begin{array}{l}\mathrm{rpb}= \\
\mathrm{p}<.0\end{array}$ & 257 & 10 & Total & $\begin{array}{r}\mathrm{rpb}= \\
\mathrm{p}<.0\end{array}$ & ${ }_{5}^{257}$ & 10 \\
\hline
\end{tabular}

But although more of the frequent offenders are caught, no more of them are booked. Seriousness of the offense enters the decision to book.

It should be borne in mind that the majority of even the most delinquent boys are unknown to the police and the courts. This comes as no surprise to the police. The point is that the one-third or less of the most delinquent boys who are caught may be a highly selected group of youngsters; and the 16 per cent of all the boys caught are not by any means equally delinquent or representative of delinquent boys. Researchers who generalize about delinquents from apprehended or adjudged delinquents should be cautioned by these data.

\section{Delinquent Behavior and Social Status}

The data to be presented now demonstrate that there is indeed an inverse relationship between delinquent behavior and social status. However, this rela.

Table 9

Relationship between Delinquency (Index F) and Social Status by Race and Sex

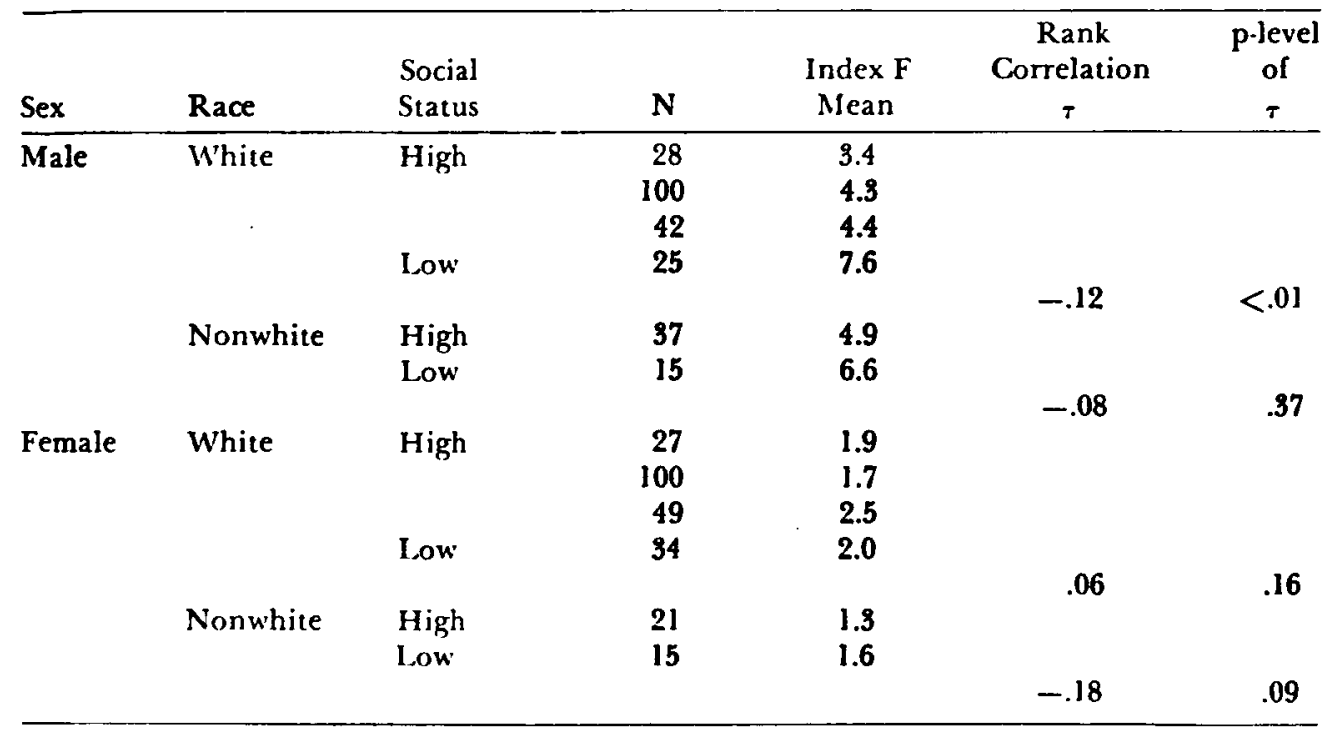


Table 10

Relationship between Delinquency (Index S) and Social Status by Race and Sex

\begin{tabular}{|c|c|c|c|c|c|c|}
\hline Sex & Race & $\begin{array}{l}\text { Social } \\
\text { Status }\end{array}$ & $\mathbf{N}$ & $\begin{array}{c}\text { Index S } \\
\text { Mean }\end{array}$ & $\begin{array}{c}\text { Rank } \\
\text { Correlation } \\
\tau \\
\end{array}$ & $\begin{array}{c}\text { p-leve } \\
\text { of } \\
r\end{array}$ \\
\hline \multirow[t]{8}{*}{$\overline{\text { Male }}$} & White & High & 28 & 4.0 & & \\
\hline & & & 100 & 4.8 & & \\
\hline & & & 42 & 5.2 & & \\
\hline & & Low & 25 & 8.3 & & \\
\hline & & & & & -.12 & $<.01$ \\
\hline & Nonwhite & High & 37 & 5.3 & & \\
\hline & & Low & 15 & 7.4 & & \\
\hline & & & & & -.05 & $>.30$ \\
\hline \multirow{8}{*}{ Female } & White & High & 27 & 2.1 & & \\
\hline & & & 100 & 1.7 & & \\
\hline & & & 49 & 2.6 & . & \\
\hline & & Low & 34 & 1.8 & & \\
\hline & & & & & -.08 & .09 \\
\hline & Nonwhite & High & 21 & 1.8 & & \\
\hline & & Low & 15 & 1.8 & & \\
\hline & & & & & -.01 & $>.30$ \\
\hline
\end{tabular}

tionship exists only among boys. Tables 9 and 10 and Figures 4 and 5 present these data.

Both indices have been divided into four levels of delinquency for the purposes of presenting the data as graphs. The lowest level of delinquency on both indices includes about 53 per cent of the youngsters; the next to lowest, about 20 per cent; the next to highest, about 15 per cent: and the highest, about 12 per cent.

Also, to make the data more clear, the measure of social status has been divided into four levels described in Table 5 .

While the presentation of data is aided by so categorizing the measures, a more sensitive test of the relationship between social status and delinquency considers the complete order from high to low in both sets of measures. Kendall's rank order correlation is used here to measure the degree of their covariation.

The data reveal no reliable relationship between delinquency and social status among girls. Among white girls, 47 per cent of the lowest status girls are in about the lower half of delinquency in- dex F, compared with 52 per cent of the highest status girls. Similarly, almost equal proportions of girls fall into the lower half of the sample on Index $S$. An inspection of the data on nonwhite, mostly Negro girls shows the same lack of relationship between delinquency and social status, although the comparison here is limited to the two lowest social status levels. These data contradict the relationship between girls' delinquency and their social status which emerges from official records. ${ }^{14}$

The pattern in the data on white boys is quite different from that for the girls. The proportion of lowest status boys climbs from 8 per cent in the lowest de. linquency category of Index $F$ to 36 per cent in the highest; the proportion of highest status boys falls from 35 per cent in the lowest category to 11 per cent in

14 William 1. Thomas, The Unadjusted Girl (Boston, Little, Brown, 1937) ; William W'. Wattenberg. "Differences betkeen Girl and Boy 'Repeaters," Journal of Educational Psychologn. March 1953, pp. 137-46; William W. Wattenberg and Frank Saunders, "Recidivism among Girls," lournal of Abnormal and Social Psyrhology, May 195.5. pp. 405.06. 
Figure 4

Percentage of Youngsters at Four Levels of Delinquency (Index F)

by Social Status and by Race and Sex

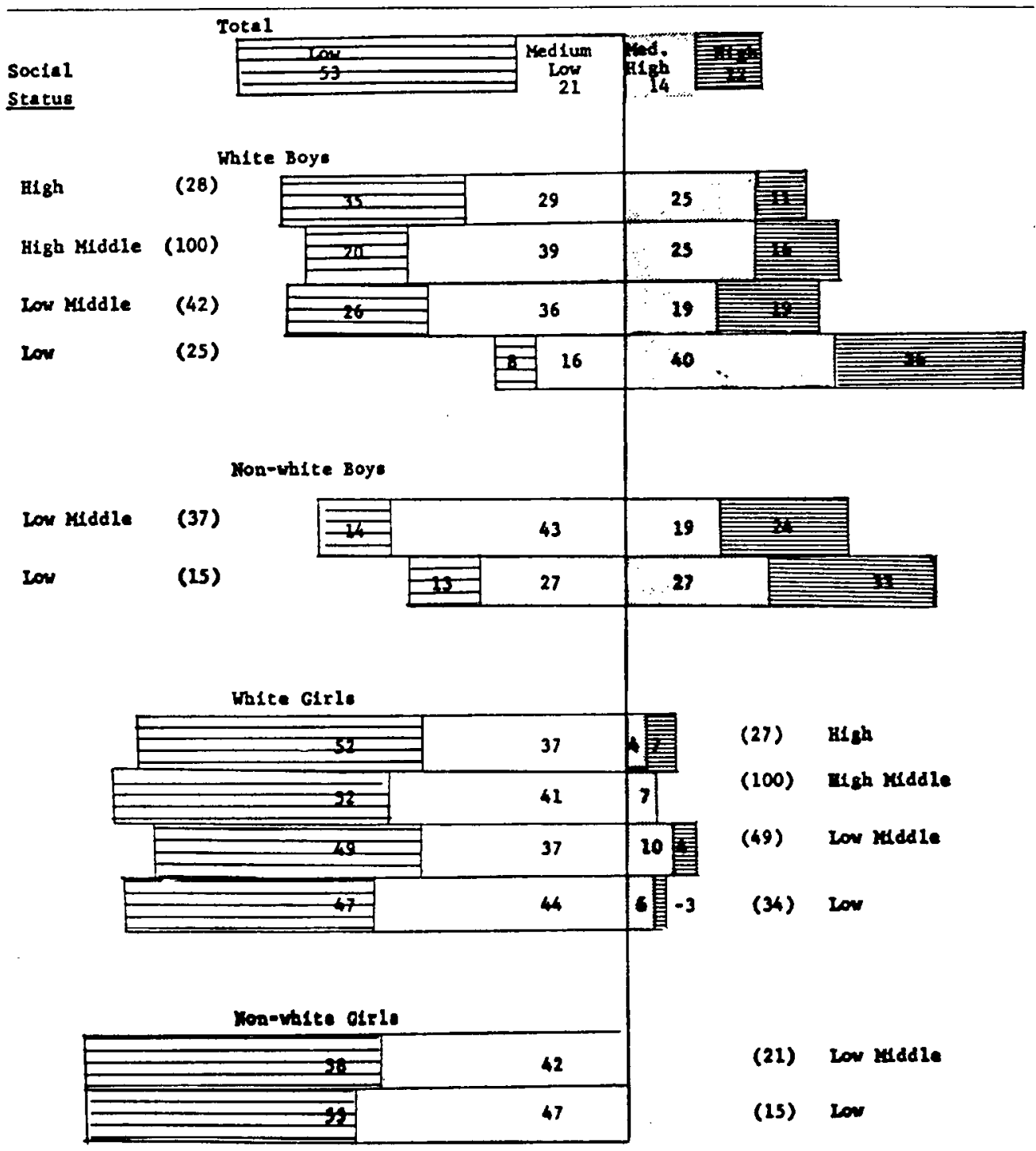

the highest category. The two middle status categories of white boys occupy intermediate positions on delinquency index $F$. The rank order correlation between social status and delinquency among white boys inclicates that this relationship could have occurred merely by chance less than once in 100 times. White boys show the same pattern on Inclex $S$ (Figure 5). Figures 4 and 5 make clear that most of the relationship between social status and delinquency among white boys is accounted for by the greater delinquency of the low'est status white boys.

Among the nonwhite boy's, the two "lelinquency indices produce somewhat different results. Neither index is correlated reliably with social status, but the range of social status among non- 
Figure 5

Percentage of Youngsters at Four Levels of Delinquency (Index S)

by Social Status and by Race and Sex

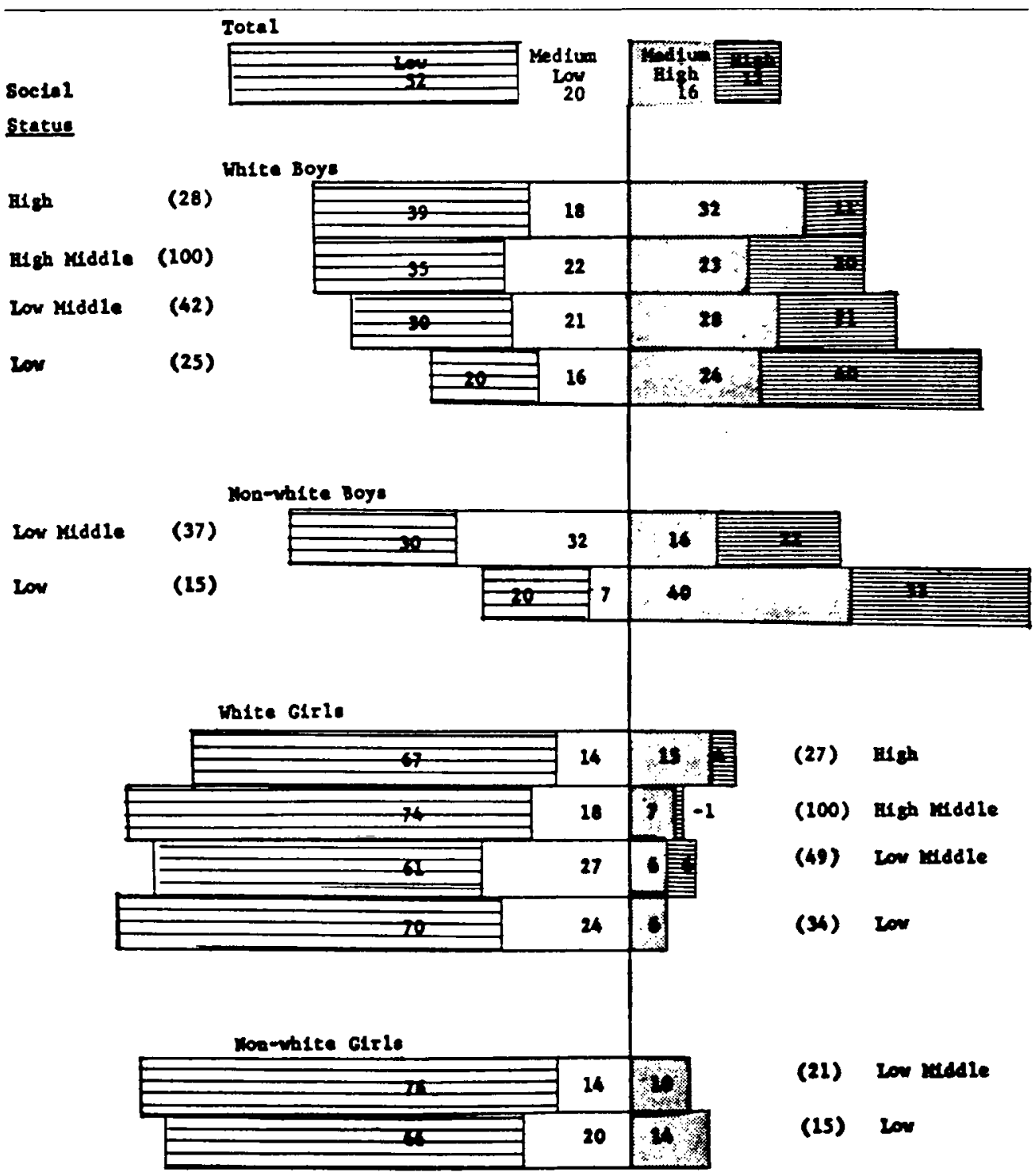

white boys is so truncated, effectively encompassing only the lowest three scores on the Duncan scale, that any rank cor. relation is limited by the data themselves. A comparison of the graphs in Figures 4 and 5 demonstrates that Index $S$, which takes seriousness of the offense into account, better discriminates be- tween higher and lower status nonwhite boys than Index $F$ does. Index $S$ puts the proportions of lower status boys below the proportions of higher status boys at the less delinquent end of the index and above the higher status boys at the more delinquent end. Two-by-two chi-square analyses bear out the different 
Table 11

Relationship between Delinquency and Social Status among Nonwhite Males: Comparing Index $F$ and Index $S$ Measures

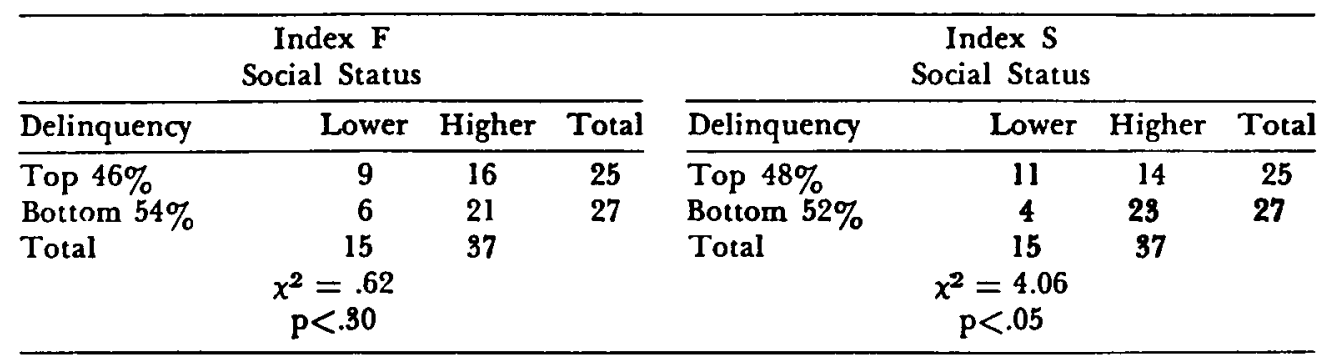

patterns obtained by the two indices (Table 11): the chi-square result from Index $F$ is reliable only at about the .40 level; from Index $S$, it is reliable at less than .05 , more lower status boys being more delinquent. So it seems that, in frequency of delinquency, the sons of non white unskilled workers do not differ much from the sons of nonwhite, semiskilled workers; but, in seriousness of offense-as defined by white, middle-class judges-the former commit more serious offenses than the latter.

So we have found that delinquent behavior among boys is related to social status, just as the much criticized official records have demonstrated over and over igain. It seems reasonable, then, to raise the question: why not continue to employ official records, at least to explore this relationship, rather than collect more expensive data?

One reason is that the official records exaggerate the differences in delinquen. cy among boys of different status levels. They make social status, in the sense of the breadwinner's occupation, seem more important than it really is as far as researchers and practitioners are concerned. About five times more lowest than highest status boys appear in the official records; if records were complete and unselective, we estimate that the ratio would be closer to $1.5: 1$.

However, there is a sense in which the actual ratio of delinquent behavior specifically among boys is closer to $5: 1$ than
1.5:1 against the lowest status boys; that is, the official records come closer to a valid picture than does the estimate of unselective records. The data in Figures 4 and 5 show that three to four times more lowest status boys than highest status boys behave at the highest delinquency level on either index. If we consider these boys to be the ones who represent the most pressing social problem and therefore should be apprehended and given attention, then the official booking rates do not depart so far from truly representing differential delinquency among social status levels.

On the other hand, if we define the social problem to include the top two levels of delinquency, then the ratio of delinquents is only about $1.5: 1$ or $2: 1$ against the lowest status boys.

This kind of discussion exposes the greatest source of invalidity inherent in official records: youngsters are categorized as "delinquent" or not categorized at all. Some researchers have found this distinction too limiting, so they have distinguished between "sometime delinquents," who appear in the official records only once, and "repeaters." 15 We share the view of other researchers in this field that it is more useful to think

15 Gold, op. cit. supra note 2; William W. Wattenberg, "A Comparison of Repeaters and Conrepeaters among Boys in Trouble with Police in Detroit in 1946 and 1947," in Michigan Academy of Science, Arts, and Letters, Papers $35,1949$. 
of delinquency as a continuous rather than as a discrete variable. One of the major advantages of our method of gathering data is that it permits us to measure delinquency in this way.

Finally, we should point out again that, according to our findings, official records are altogether invalid when they reflect a difference in degree of delinquency among social status levels for girls. It is true that our validation study revealed that girls tend to conceal fornication, on offense thought to account for a substantial portion of girls' delinquency. Nevertheless, the validation data give us no reason to believe that there are differences in concealment among social status levels. As far as we can tell from our data, delinquency among girls is not related to their social status.

\section{Theoretical Implications}

We noted near the beginning of this paper that major theories of delinquency are based on the inverse relationship between the degree of delinquency and social status. We noted, too, that the reality of this relationship has been questioned and that data have been produced to refute it.

On the basis of the data reported here, we conclude that the inverse relationship is indeed a fact among boys. (The theories of delinquency to which we have alluded have been implicitly, if not explicitly, limited to delinquency among boys.)

It seems that studies of undetected delinquency by interview methods consistently find a relationship with social status among boys, ${ }^{10}$ while those which use self-administered checklists do not. ${ }^{17}$

\footnotetext{
16 Maynard L. Erickson and LaMar T. Empey, "Class Position, Peers, and Delinquency," Sociology and Social Research, April 1965, pp. 268-82; Reiss and Rhodes, supra note 7.

17 Clark and Wenninger, supra note 5; Dentler and Monroe, supra note 5; Jerome Himelhoch, "Socio-Economic Status and Delinquency in Rural New England" (paper read at the annual meeting of the American Sociological Association, Montreal, 1964); Nye, op. cit. supra
}

Perhaps the tendency we have found here for higher status youngsters more of ten to report nonchargeable behavior as delinquent obscures the relationship with social status in checklist data. Perhaps, in addition, social status itself is too roughly ascertained in a self-administered questionnaire.

Our data are limited to one city. However, we suspect that, in regard to delinquency, Flint is not different from any other community encompassing a fairly broad range of social status categories. We suspect that these same findings will hold not only for other urban communities but also for rural communities. We intend to do research on this problem.

Data presented here do not permit us to choose among the various theories of delinquency which are based on its relationship to social status. ${ }^{18}$ The low correlation of delinquency with social status, however reliable that relationship is, suggests that it is time to examine empirically the links between social status and delinquency to see whether we can discover the more potent determinants to which social status is but a scant clue.

These data are only a small part of the total collected on this project. Data are now being organized around such topics as differences in sex, age, and race, the composition of delinquent groups, delinquent "loners," seasonal variations, the location of delinquent acts, types of delinquents, educational and vocational aspirations of youngsters related to their delinquency, school achievement, and so on.

note 5; Gerald J. Pine, The Significance of the Relationships between Social Class Status, Social Mobility, and Delinquent Behavior, unpublished doctoral dissertation, Boston University School of Education, 1963; Porterfield and Clifton, op. cit. supra note 5.

18 Cohen, op. cit. supra note 3; Gold, op. cit. supra note 2; Cloward and Ohlin, op. cit. supra note 3; William C. Kvaraceus and Walter B. Miller, eds., Delinquent Behavior: Culture and the Individual (Washington, D.C.: National Education Association, 1959). 
As for girls, it seems that social scientists will have to search for theoretical bases different from a relationship with social status. Relatively little systematic research has been done on delinquency among girls ${ }^{18}$; the emphasis has been on

19 Ruth R. Morris, "Female Delinquency and Relational Problems," Social Forces, October 1964, pp. 82-89; Thomas, supra note 14; Wattenberg, supra note 14 . emotional disturbance and family relationships. While this study has only a little to say about these factors, it will perhaps turn up enough new information about the nature of delinquency among girls to throw some light on the problem. Our data here already indicate that girls are far less delinquent than boys. Further analyses of data are proceeding. 